\title{
Sistem Monitoring Ketersediaan Air pada Perangkat Cuci Tangan Portable berbasis IoT
}

\section{DADAN NUR RAMADAN, SUGONDO HADIYOSO, INDRARINI DYAH IRAWATI}

Fakultas Ilmu Terapan, Universitas Telkom, Bandung, Indonesia

Email: dadannr@telkomuniversity.ac.id

Received 13 Januari 2021 | Revised 2 Februari 2021 | Accepted 9 Februari 2021

\begin{abstract}
ABSTRAK
Pada studi ini diimplementasikan sebuah sistem untuk memantau ketinggian air di dalam drum secara online real-time menggunakan platform Internet of Things (IoT). Sistem ini terdiri dari sensor ultrasonik untuk estimasi ketinggian air, kemudian data tersebut dikirim ke firebase cloud database, untuk diakses oleh perangkat monitoring atau mengakses halaman website. Level air yang tersisa direpresentasikan dalam nilai persen (\%). Rata-rata kesalahan pembacaan sensor adalah tidak lebih dari 2\%. Delay pengiriman yang digenerate adalah 39,06 ms, sesuai dengan rekomendasi ITU-T untuk komunikasi real-time. Sistem informasi web dapat menampilkan data ketinggian air dalam bentuk numerik dan grafik. Sistem ini telah diterapkan di sekolah menengah pertama Al-Azhar kota Bandung dan diharapkan dapat diperluas penerapannya.
\end{abstract}

Kata kunci: drum, ketinggian air, real-time, IoT

\begin{abstract}
In this study, a real-time online monitoring of the water level in the drum was implemented using the internet of things (IoT) platform. This system consists of ultrasonic sensors to estimate the water level, then the data is sent to the Firebase cloud database, to be accessed by monitoring devices or accessing a website page. Water level is represented as a percent (\%). The average sensor reading error is not more than 2\%. The generated delivery delay is $39.06 \mathrm{~ms}$, according to ITU-T recommendations for real-time communication. The web information system can display water level data in numerical and graphic form. This system has been implemented in Al-Azhar junior high school in Bandung and it is hoped that its application can be expanded.
\end{abstract}

Keywords: drums, water level, real-time, IoT 


\section{PENDAHULUAN}

Protokol kesehatan seperti menjaga jarak, menggunakan masker, mencuci tangan atau dikenal dengan 3M adalah tindakan yang wajib diterapkan dalam masa pandemi Covid-19 mengacu pada surat edaran Menteri Kesehatan No. HK.02.01/MENKES/216/2020 (Kemenkes RI, 2020). Fasilitas umum atau tempat umum wajib menyediakan sarana untuk cuci tangan yang memadai baik kuantitas maupun kualitas. Bersamaan dengan itu, pemerintah Indonesia melalui kebijakan pemerintah daerah dan satuan tugas penanganan Covid-19 mulai mengkaji pembukaan sekolah untuk melaksanakan pembelajaran tatap muka. Sebagai salah satu bentuk persiapan maka sekolah-sekolah mulai menyediakan sejumlah perangkat untuk cuci tangan, beberapa portable dan beberapa lainnya permanen. Tempat cuci tangan portable umumnya menggunakan drum sebagai penampung air. Ini memang sangat fleksibel dan sederhana dalam instalasi. Namun demikian, ketersediaan air di dalam drum harus dilakukan pengecekan berkala secara manual. Ini menjadi pekerjaan yang kurang efisien jika tempat cuci tangan portable dipasang dalam jumlah banyak. Untuk mengatasi masalah ini, maka dibutuhkan sebuah sistem yang dapat memantau kondisi ketinggian air pada drum tersebut.

Sistem pemantauan ketersediaan air dapat dilakukan dengan memasang sensor pada saluran air dan pada bak penampung. Sistem pertama dapat memberikan informasi jumlah air yang telah digunakan dan sistem kedua digunakan untuk memantau volume air yang tersedia. Ariessanti, dkk, merealisasikan sebuah sistem monitoring penggunaan air bersih pada saluran PDAM pelanggan secara online melalui website (Ariessanti, dkk, 2020). Studi oleh Wibowo, mengusulkan sebuah sistem untuk memantau ketinggian air pada tangki untuk mengendalikan pompa secara otomatis (Wibowo, 2017). Sistem ini menggunakan sensor ultrasonic untuk deteksi level air. Studi oleh Yusman, merealisasikan perangkat telemetri untuk memonitor ketinggian air sungai berbasis pesan singkat (SMS) (Yusman, 2013). Penelitian serupa pada aplikasi monitoring ketinggian air sungai berbasis SMS juga dilaporkan pada studi (Halim, dkk, 2019) (Tenggono, dkk, 2015). Namun demikian, teknologi transmisi data melalui SMS memerlukan perangkat seperti handphone sehingga memerlukan biaya lebih tinggi. Monitoring ketinggian permuakaan air berbasis web diusulkan juga pada studi (Fikri, dkk, 2015). Studi lainnya oleh Abdurahman, merancang sebuah sistem monitoring berikut kendali pintu air secara otomatis dimana aplikasi dibangun menggunakan LabView (Abdurahman, 2018). Namun demikian, monitoring dan kendali ini tidak dapat dilakukan melalui perangkat handphone. Penelitian lain oleh Watty, merealisasikan prototipe untuk memonitor ketinggian air dalam sebuah tempat penampung air dengan media transmisi bluetooth untuk mengirim data ke handphone (Watty, dkk, 2019). Penelitian serupa tentang aplikasi monitoring ketinggian air berbasis bluetooth juga dilaporkan pada studi (Permana, dkk, 2015) (Tanuatmadja \& Wijono, 2017). Namun demikian, penggunaan bluetooth tentu memiliki keterbatasan jarak transmisi.

Dari beberapa penelitian yang sudah ada belum terdapat studi yang mendesain sebuah sistem untuk memonitor ketinggian air pada drum dengan menerapkan sistem multimode. Oleh karena itu, pada studi ini mengusulkan sebuah sistem untuk memantau ketinggian air di dalam drum secara online dan real-time pada sebuah aplikasi berbasis web. Sistem yang diusulkan juga mendukung untuk diaplikasikan pada sejumlah node. Sistem ini terdiri dari sensor ultrasonic untuk estimasi ketinggian air dan modul wifi mikrokontroler untuk transmisi data ke jaringan internet eksisting. 


\section{METODE DAN PERANCANGAN}

Untuk mengetahui volume air berdasarkan ketinggian air yang ada di dalam drum perangkat cuci tangan portable menggunakan konsep seperti ditampilkan pada Gambar 1 berikut.

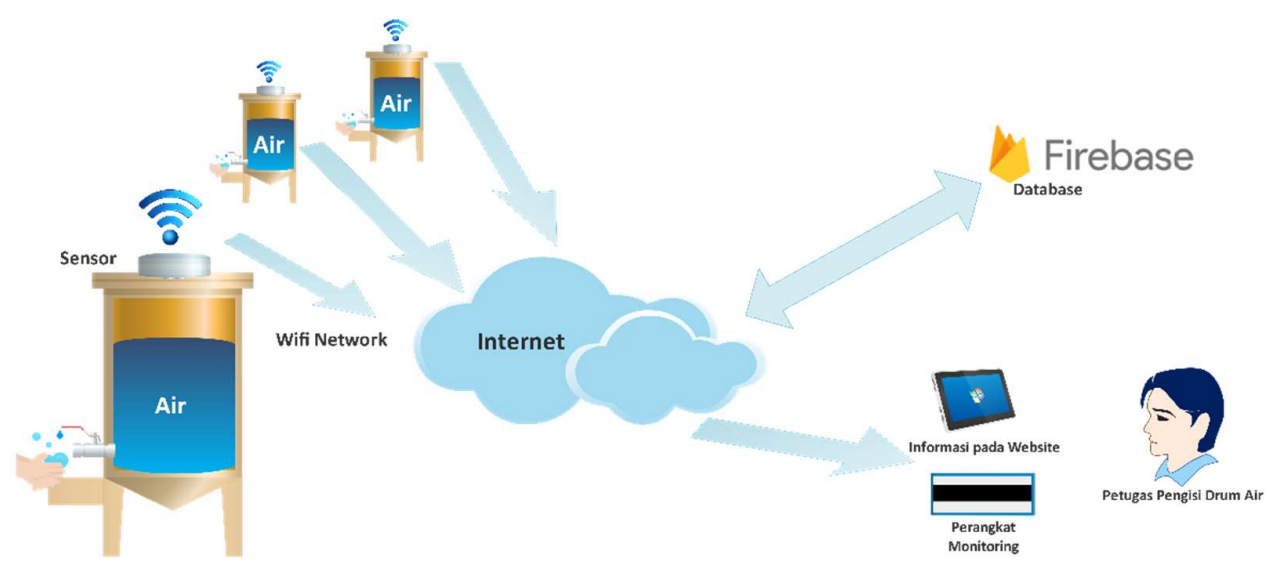

Gambar 1. Blok Sistem Monitoring Ketersediaan Air pada Drum

Berdasarkan Gambar 1, pada bagian atas drum air ditempatkan sebuah alat untuk mengetahui ketinggian air pada setiap drum, perangkat tersebut terdiri dari sebuah sensor ultrasonic, LCD Display dan Mikrokontroler NodeMCU, dengan skematik diagram seperti pada Gambar 2. Sementara itu, skematik diagram tampilan informasi ditunjukkan pada Gambar 3. Setiap perangkat monitoring air, memiliki spesifikasi yang sama, kemudian dibedakan berdasarkan ID pada NodeMCU sebagai identitas data pada setiap drum air perangkat cuci tangan portable. NodeMCU adalah sebuah mikrokontroler yang sudah terintegrasi dengan modul internet ESP8266, yang dapat digunakan untuk mengirim dan menerima data dari firebase (Wicaksono, dkk, 2019).

Berdasarkan Gambar 2 sensor ultrasonic berfungsi untuk membaca ketinggian air yang berada di dalam drum, kemudian hasil pembacaan dari sensor ultrasonic tersebut akan diolah menjadi besaran volume oleh mikrokontroler NodeMCU, kemudian nilai volume akan dikirimkan ke firebase cloud database, untuk disimpan, dan ditampilkan pada perangkat atau website monitoring ketinggian air. Firebase adalah layanan dari google, di mana di dalamnya memiliki fitur yang dapat digunakan untuk penyimpanan data yaitu real time database, yang dapat diakses dengan menggunakan protoco/http (Ramadan, dkk, 2019).

Sensor ultrasonic terhubung pada PIN D7 dan PIN D8 NodeMCU, setiap PIN tersebut memiliki fungsi di mana PIN D7 sebagai trigger yang berfungsi untuk membangkitkan sinyal ultrasonic, sedangkan PIN D8 sebagai echo atau menerima sinyal pantulan ultrasonic (Renaldi, dkk, 2018). Trigger akan mengirimkan gelombang ultrasonic dengan frekuensi $40 \mathrm{kHz}$ setiap 10 uS (Sdn, 2013), gelombang ini akan melalui udara kira-kira dengan kecepatan 340 m/detik, apabila gelombang ini membentur suatu objek atau air, maka gelombang akan dipantulkan kembali ke sensor dan diterima oleh echo, seperti pada Gambar 4. 


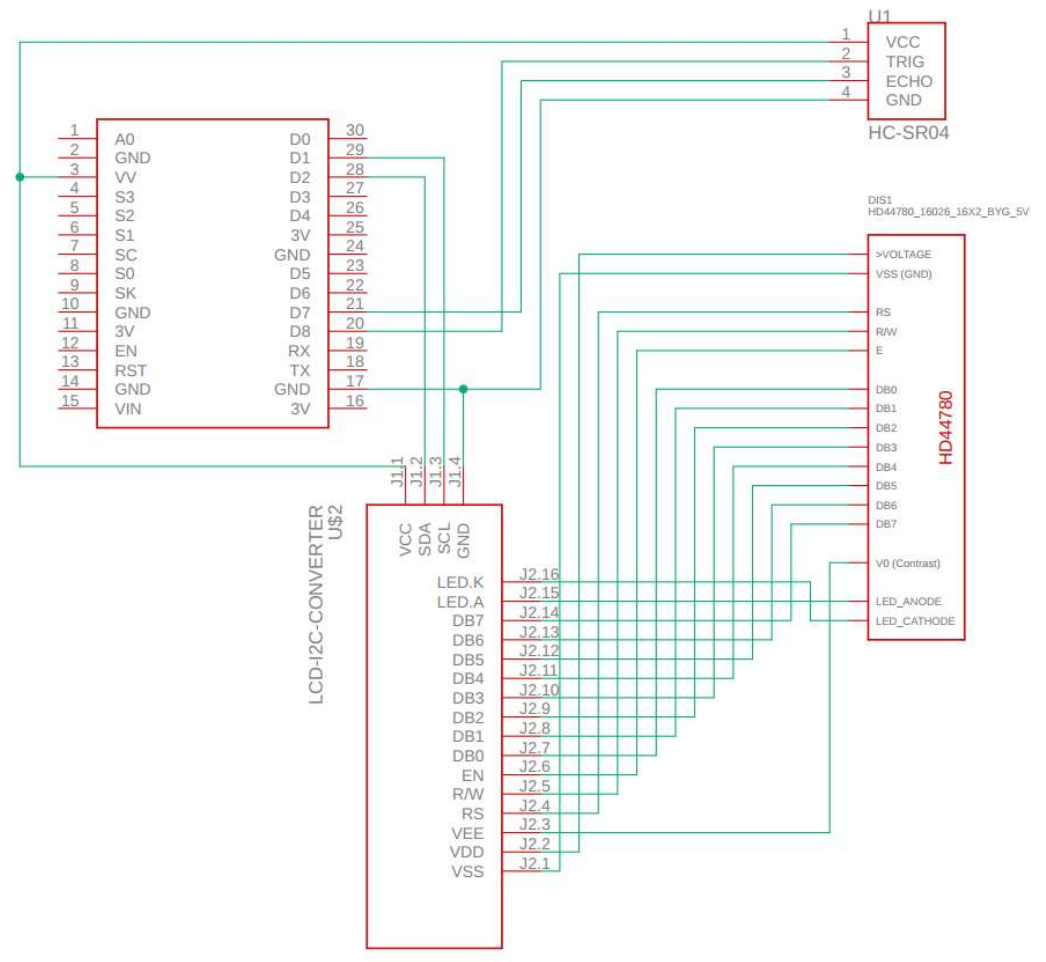

Gambar 2. Skematik Sensor Monitoring Air pada Drum

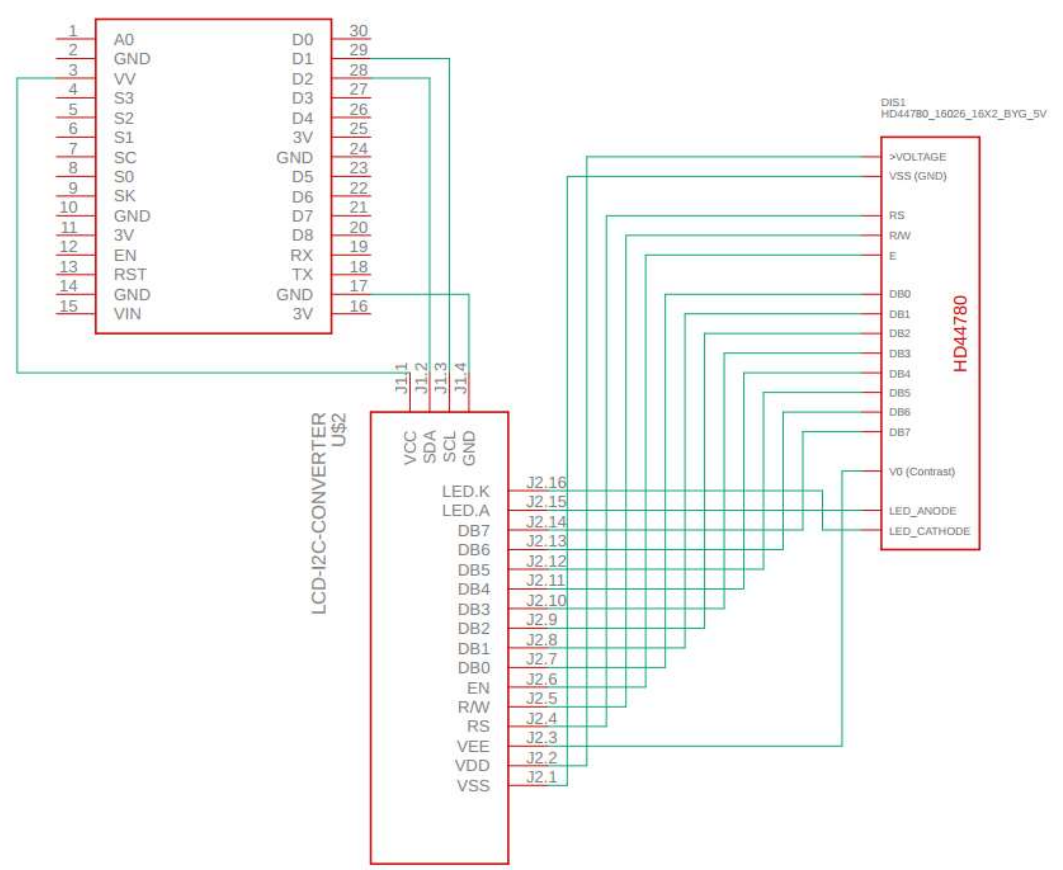

Gambar 3. Skematik Perangkat Informasi Ketinggian Air Dalam Drum 


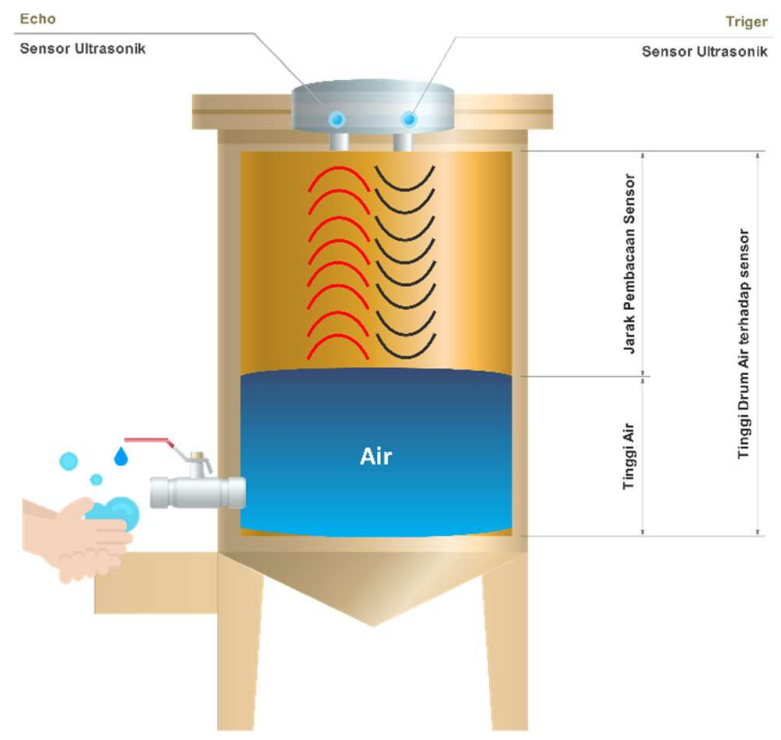

Gambar 4. Cara Kerja Sensor Ultrasonic

Dengan mengukur jeda waktu dari gelombang yang dikirimkan oleh trigger terhadap pantulan gelombang yang diterima oleh echo, maka tinggi tabung yang tidak terisi oleh air dapat dihitung seperti yang ditunjukkan pada Persamaan (1) berikut:

$$
\text { Jarak }=\frac{\text { Kecepatan Gelombang } x \text { waktu }}{2}(\mathrm{~cm})
$$

dimana kecepatan gelombang $=340 \mathrm{~m} / \mathrm{s}$ dan waktu dalam satuan detik.

Waktu perambatan gelombang dapat dihitung menggunakan Persamaan (2) berikut:

$$
\text { Waktu }=\frac{2 \times \operatorname{jarak}(\mathrm{cm})}{\text { KecepatanGelombang }}(\text { detik })
$$

Untuk jarak $1 \mathrm{~cm}$ maka waktu perambatan gelombang adalah

$$
\text { Waktu }=\frac{2 \times 10^{-2} \times 1 \mathrm{~cm}}{340 \mathrm{~m} / \mathrm{s}}=58,14 \times 10^{-6} \text { detik }
$$

Sehingga untuk menentukan tinggi air di dalam drum dapat dihitung dengan membandingkan waktu pantulan persentimeter, menggunakan waktu (t) lalu dikalikan dengan $1 \mathrm{~cm}$. Dengan ketinggian maksimum air di dalam drum adalah $100 \mathrm{~cm}$, maka ketinggain air adalah $100 \mathrm{~cm}$ dikurangi dengan jarak pembacaan air oleh sensor.

Dengan Modul ESP-8266 yang terdapat pada NodeMCU, data ketinggaian air tersebut kemudian dikirim ke internet, melalui perantara hotspot atau wireless access point ke firebase cloud database, untuk disimpan. Data tersebut kemudian diakses oleh perangkat monitoring atau mengakses halaman website, Berikut pada Gambar 5 adalah tampilan dari firebase cloud database, di mana data dari seluruh setiap drum perangkat cuci tangan portable disimpan, dan tampilan website informasi ketinggian air disajikan pada Gambar 6. 


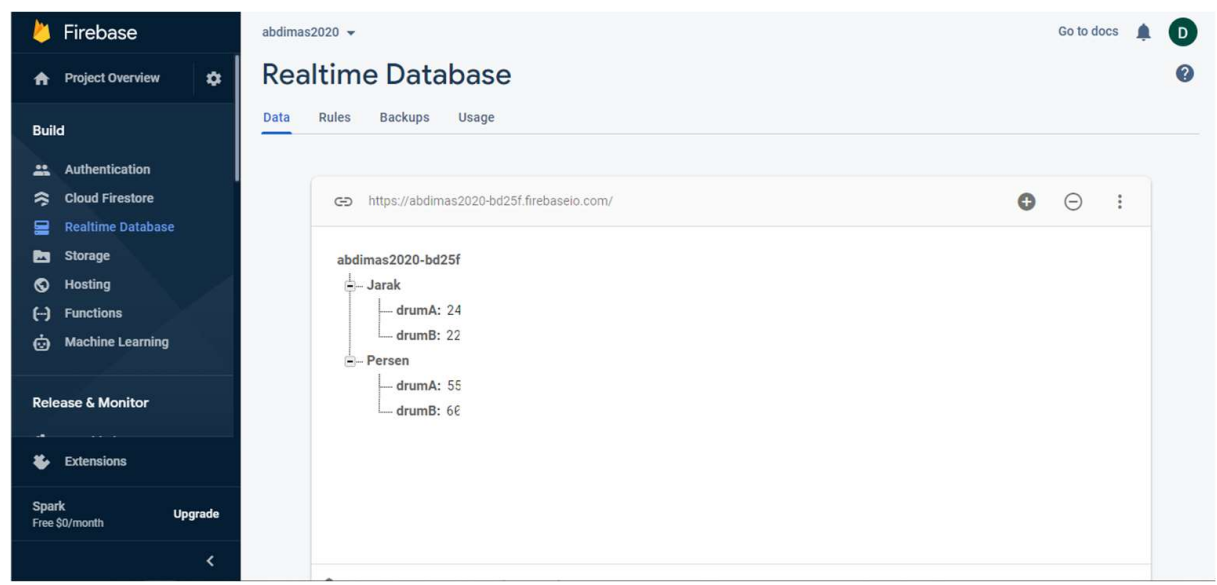

Gambar 5. Tampilan Firebase Cloud Database

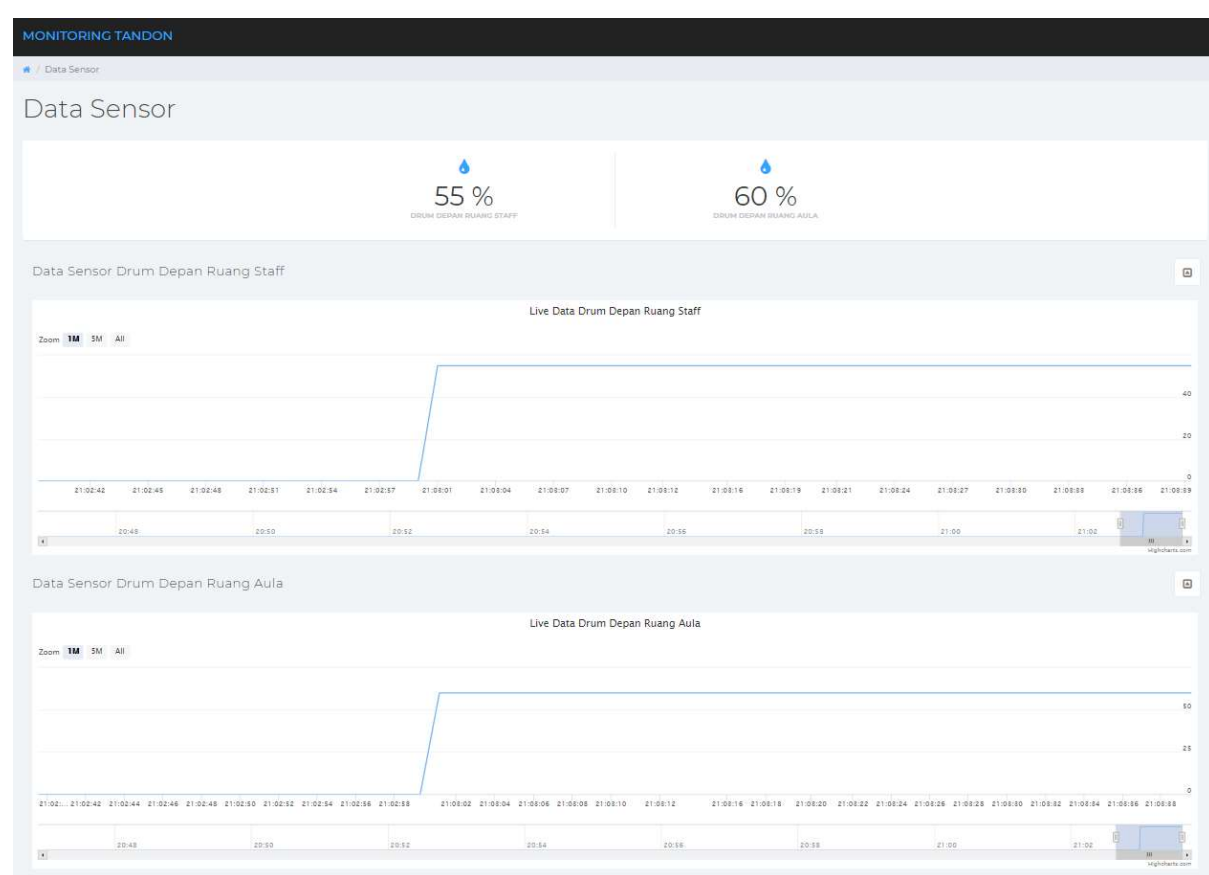

Gambar 6. Tampilan Website Informasi Ketinggian Air pada Drum Perangkat Cuci Tangan

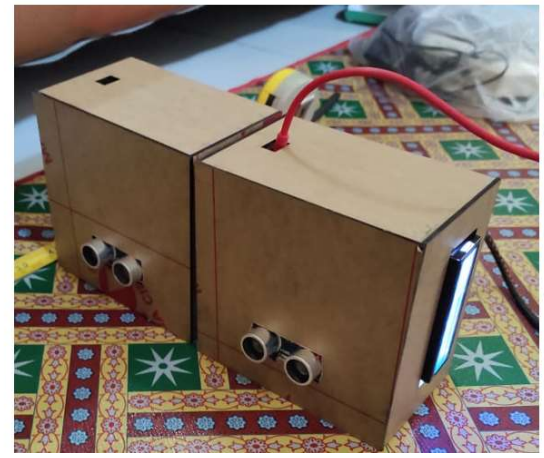

(a)

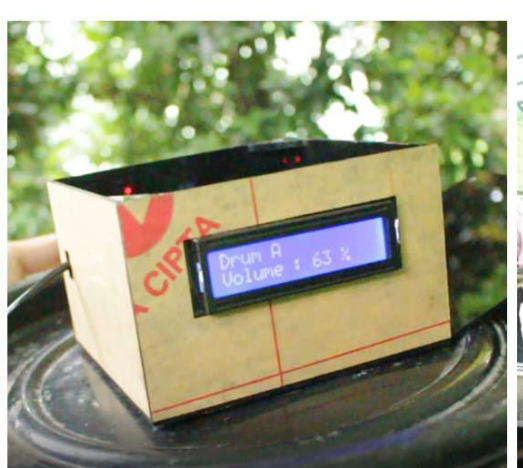

(b)

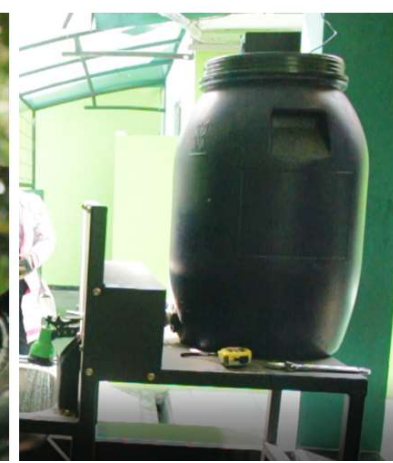

(c)

Gambar 7. Perangkat Sensor Ketinggian Air (a) Sensor (b) Display (c) Penempatan Sensor pada Drum

ELKOMIKA - 460 
Pada Gambar 7 adalah implementasi sistem monitoring air pada drum perangkat cuci tangan portable. Pada Gambar 7(a) adalah perangkat sensor untuk monitoring ketinggian air pada drum cuci tangan portable, Gambar 7(b) adalah tampilan pembacaan sisa air yang tersedia di dalam drum, sedangkan Gambar 7(c) adalah penempatan sensor di atas drum cuci tangan portable.

\section{PENGUJIAN DAN DISKUSI}

Pengujian mencakup akurasi pembacaan sensor terhadap ketinggian air dalam drum dan pengukuran besaran paket data.

\subsection{Akurasi Pembacaan Sensor}

Berdasarkan hasil pengujian akurasi pembacaan sensor ultrasonic untuk membaca ketinggian air ditunjukkan pada Gambar 8. Kesalahan pembacaan sensor ditunjukkan pada Gambar 9.

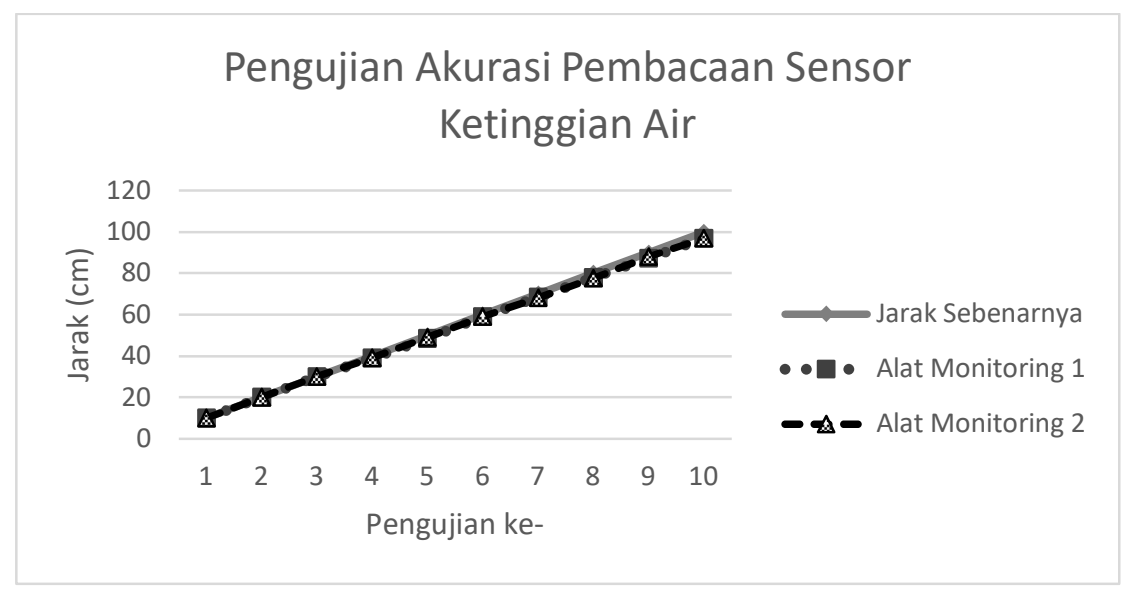

\section{Gambar 8. Pengujian Akurasi Pembacaan Sensor Ketinggian Air}

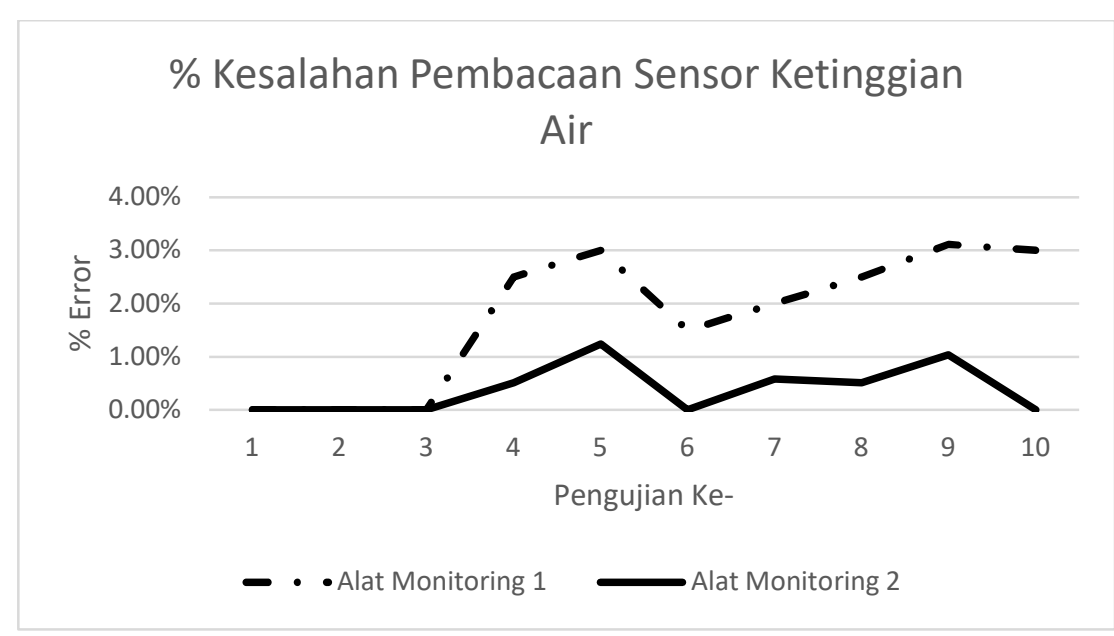

\section{Gambar 9. Kesalahan Pembacaan Sensor Ketinggian Air}

Dari sepuluh pengujian terhadap sensor ultrasonic dalam membaca jarak, dua sensor yang digunakan dalam studi ini menghasilkan kesalahan pembacaan rata-rata tidak lebih dari 0.02 . Ini berarti kesalahan pembacaan pada drum dengan ketinggian $100 \mathrm{~cm}$, kesalahan pembacaan 
tidak lebih dari $2 \mathrm{~cm}$. Dengan nilai kesalahan deteksi tersebut nantinya akan berpengaruh terhadap akurasi sistem dalam mengestimasi volume air pada drum yang dibahas pada bagian selanjutnya.

\subsection{Pengukuran Volume Air pada Drum}

Skenario berikutnya adalah pengujian estimasi volume air berdasarkan level air yang terdeteksi oleh sensor. Volume air direpresentasikan dalam nilai persen (\%) untuk dikirimkan dan ditampilkan pada aplikasi. Dalam melakukan estimasi dimaksud maka ditentukanlah sebuah persamaan linear pada kondisi ideal yang dihitung berdasarkan variabel ketinggian dan volume air pada Tabel 1 berikut.

\section{Tabel 1. Variabel Input dan Output Dalam Menentukan Persamaan Regresi Linear}

\begin{tabular}{|c|c|}
\hline Tinggi Air (cm) & \% Volume \\
\hline 80 & 100 \\
\hline 70 & 90 \\
\hline 60 & 80 \\
\hline 50 & 70 \\
\hline 40 & 55 \\
\hline 30 & 40 \\
\hline 20 & 25 \\
\hline 10 & 15 \\
\hline 5 & 5 \\
\hline 0 & 0 \\
\hline
\end{tabular}

Dari kalkulasi, koefisien atau variabel bebas dan tidak bebas dituangkan dalam Persamaan (3) linear berikut:

$$
y=1.2889 x-0.9521
$$

Dari Persamaan (3), $y$ adalah estimasi volume dan $x$ adalah tinggi level air yang terdeteksi. Dengan menerapkan persamaan tersebut pada keadaan riil maka diperoleh estimasi volume air seperti yang ditunjukkan oleh garis berwarna merah pada Gambar 10. Dari perhitungan ini maka terdapat kesalahan deteksi volume air sebagaimana ditunjukkan oleh Tabel 2.

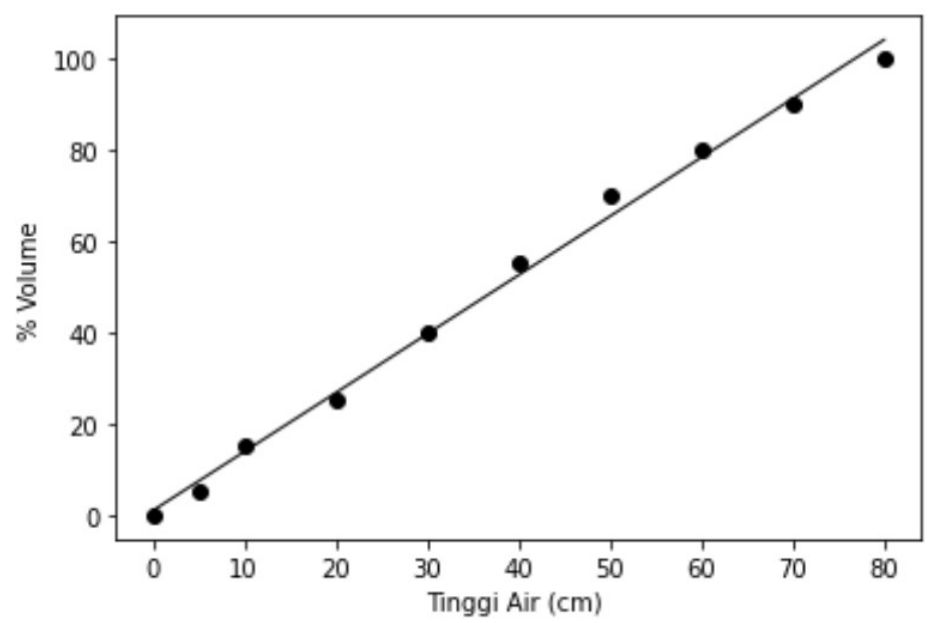

Gambar 10. Estimasi Volume Air Berdasarkan Persamaan Regresi Yang Diimplementasikan

ELKOMIKA - 462 
Tabel 2. Estimasi Volume Air dan Kesalahan Deteksi

\begin{tabular}{|c|c|c|c|}
\hline Tinggi Air (cm) & \% Volume Terdeteksi & \% Volume riil & Kesalahan \\
\hline 80 & 104,1 & 100 & 0,041 \\
\hline 70 & 91,2 & 90 & 0,012 \\
\hline 60 & 78,3 & 80 & 0,017 \\
\hline 50 & 65,4 & 70 & 0,046 \\
\hline 40 & 52,5 & 55 & 0,025 \\
\hline 30 & 39,6 & 40 & 0,004 \\
\hline 20 & 26,7 & 25 & 0,017 \\
\hline 10 & 13,8 & 15 & 0,012 \\
\hline 5 & 7.4 & 5 & 0,024 \\
\hline 0 & 0.95 & 0 & 0,0095 \\
\hline \multicolumn{4}{|r}{} \\
\hline
\end{tabular}

Dari Tabel 2 dapat diketahui bahwa rata-rata kesalahan estimasi volume air dari sepuluh pengujian adalah 0,0207 atau jika terdapat air 100 liter maka delta kesalahan estimasi air mendekati 2 liter. Hasil ini menunjukkan konsistensi kesalahan dalam deteksi tinggi level air sebesar $2 \mathrm{~cm}$ sebagaimana telah dijelaskan pada pembahasan sub bagian sebelumnya. Namun demikian kesalahan yang dihasilkan ini relatif kecil dan dapat ditoleransi karena sistem yang dikembangkan ini tidak memerlukan akurasi tinggi.

\subsection{Pengukuran Paket Data}

Pengujian ini dimaksudkan untuk mengukur besar paket data yang dikirimkan oleh perangkat sensor. Pengujian ini dilakukan dengan menggunakan aplikasi Wireshark. Hasil pengujain yang dilakukan ditampilkan pada Gambar 11.

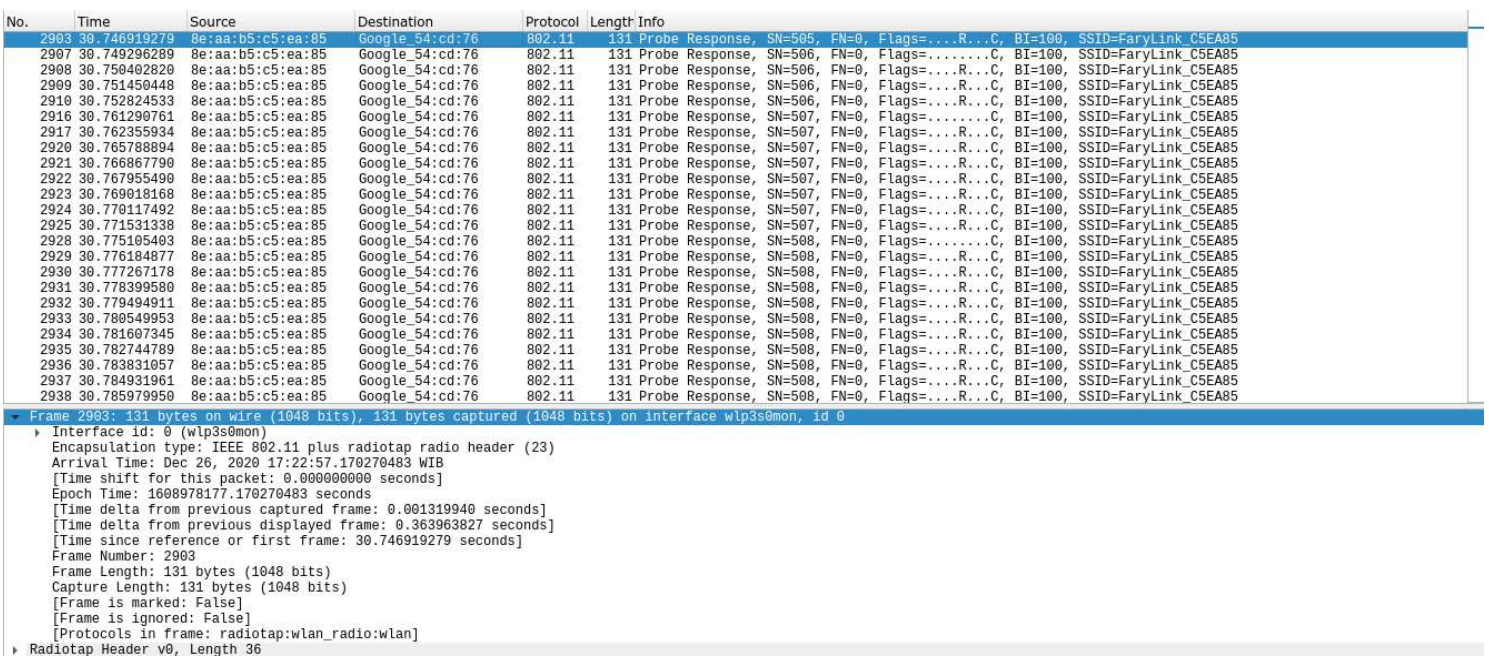

\section{Gambar 11. Pengukuran Besar Paket Data}

Pengukuran ini dilakukan dengan menggunakan sebuah laptop sebagai monitor untuk mencatat seluruh traffic pada access point yang digunakan untuk menghubungkan setiap perangkat sensor. Berdasarkan 24 kali pengujian diperoleh bahwa masing-masing paket mempunyai ukuran 131 bytes/1048 bits. Dari pengukuran ini dapat diketahui juga delay pengiriman data sebesar 39,06 ms. Delay pengiriman yang dihasilkan mempunyai nilai 
bervariasi dan ini sangat bergantung dari kondisi jaringan internet yang digunakan. Namun demikian delay yang terukur pada setiap paket tidak lebih dari 100 ms. Merujuk pada rekomendasi ITU-T, sistem monitoring online yang dibangun ini memenuhi kriteria real time di mana delay transmisi data kurang dari 250 ms dengan variasi delay yang relatif kecil (Berger, dkk, 2018).

\section{KESIMPULAN}

Sistem monitoring ketersediaan air pada drum untuk wastafe/ cuci tangan portable berbasis IoT dengan aplikasi berbasis web berhasil diimplementasikan di SMPI Al Azhar 36 Bandung. Sistem dirancang menggunakan sensor ultrasonic untuk estimasi ketinggian air pada drum. Modul wifi mikrokontroler digunakan untuk transmisi data ke jaringan internet eksisting. Data ketinggian air dari setiap node berhasil dikirim ke internet, melalui perantara wireless access point yang tersedia ke firebase cloud database. Data tersebut dapat diakses oleh perangkat monitoring yang ditampilkan pada LCD dalam bentuk persentase (\%). Selain itu monitoring juga dapat dilakukan dengan mengakses halaman website. Hasil pengujian sistem menunjukkan bahwa perangkat pengukur ketinggian air dapat bekerja sesuai desain awal, di mana level air yang tersisa direpresentasikan dalam nilai persen (\%) dengan rata-rata kesalahan pembacaan sensor kurang dari $2 \%$. Hasil uji terhadap pengiriman data menunjukkan delay yang dihasilkan adalah $39,06 \mathrm{~ms}$, ini memenuhi kriteria ITU-T untuk sistem monitoring real time. Hasil lainnya adalah bahwa sistem informasi web yang dibangun dapat menampilkan data ketinggian air dalam bentuk numerik dan grafik. Sistem yang dikembangkan ini diharapkan dapat diterapkan pada jaringan yang lebih luas dengan jumlah drum lebih banyak dan besar drum yang bervariasi.

\section{DAFTAR RUJUKAN}

Abdurahman, A. (2018). Model Sistem Monitoring Dan Kendali Pintu Air Otomatis

Berbasis Arduino dan LabView. Journal of Electrical Power, Instrumentation and Control, 1(1), 1-7. https://doi.org/10.32493/epic.v1i1.1038

Ariessanti, A. D., Martono, M., \& Afrizal, F. (2020). Prototype Sistem Monitoring Penggunaan Air Berbasis Internet of Things Pada Pdam Tirta Benteng Kota

Tangerang. ICIT Journal, 6(1), 82-93. https://doi.org/10.33050/icit.v6i1.863

Berger, L. T., Yonge, L., Abad, J., Afkhamie, K., Guerrieri, L., Katar, S., Lioe, H., Pagani, P., Riva, R., Schneider, D. M., \& Schwager, A. (2018). HomePlug AV2: NextGeneration Broadband over Power Line *. MIMO Power Line Communications, 391-426. https://doi.org/10.1201/b16540-14

Fikri, R., Lapanporo, B. P., \& Jumarang, M. I. (2015). Rancang Bangun Sistem Monitoring Ketinggian Permukaan Air Menggunakan Mikrokontroler ATMEGA328P Berbasis Web Service. Positron, 5(2), 42-48. https://doi.org/10.26418/positron.v5i2.11666

G. L. Wicaksono, I. F. Achmad, U. S., D. A. N. (2019). Sistem Kontrol Dan Monitoring 
Sistem Monitoring Ketersediaan Air pada Perangkat Cuci Tangan Portable Berbasis IoT

Kipas Angin Pada Ruang Kelas Berbasis Internet of Things Class Rooms Fan Controlling and Monitoring. Jurnal Elektro Telekomunikasi Terapan, 6(1), 721733.

Halim, S. R., Poerwanto, B., Muis, I., \& Susilawati, F. E. (2019). Rancang Bangun Prototype Sistem Monitoring Ketinggian Air Sungai Berbasis Mikrokontroler Arduino dan SMS Gateway Sebagai Upaya Deteksi Banjir Secara Dini (Mitigasi Banjir). Prosiding Semantik 2019, (pp. 317-324).

Kemenkes RI. (2020). Surat Edaran Nomor HK.02.01 /Menkes/216/2020 Tentang Protokol Pencegahan Penularan Coronavirus Disease (Covid- 19) di Tempat Kerja. Surat Edaran Nomor HK.02.01/Menkes/216/2020, 1-4.

Permana, A., Triyanto, D., \& Rismawan, T. (2015). Rancang Bangun Sistem Monitoring Volume Dan Pengisian Air Menggunakan Sensor Ultrasonik Berbasis Mikrokontroler Avr Atmega8. Coding Jurnal Komputer dan Aplikasi Untan, 3(2), 76-87.

Ramadan, D. N., Hadiyoso, S., \& Sakti, A. R. (2019). Internet of things: Roboboat for water area monitoring using $4 \mathrm{~g}$ network and google firebase. Proceeding - 2019 International Conference of Artificial Intelligence and Information Technology, ICAIIT 2019, (pp. 234-237). https://doi.org/10.1109/ICAIIT.2019.8834532

Renaldi, L., Hadiyoso, S., \& Ramadan, D. N. (2018). Purwarupa Radar sebagai Pendeteksi Benda Diam menggunakan Ultrasonik. ELKOMIKA: Jurnal Teknik Energi Elektrik, Teknik Telekomunikasi, \& Teknik Elektronika, 6(3), 317. https://doi.org/10.26760/elkomika.v6i3.317

Sdn, C. T. (2013). Product User's Manual-HCSR04 Ultrasonic Sensor User's Manual Product User's Manual-HCSR04 Ultrasonic Sensor Index. 1-10. https://cdn.datasheetspdf.com/pdf-down/H/C/-/HC-SR04-Cytron.pdf

Tanuatmadja, R., \& Wijono, F. X. S. (2017). Perancangan Sistem Monitoring dan Controlling Pompa Air secara Wireless Berbasis Android. Tes/a, 19(2), 124-132. http://dx.doi.org/10.24912/tesla.v19i2.2695

Tenggono, A., Wijaya, Y., Kusuma, E., \& Welly. (2015). Sistem Monitoring dan Peringatan Ketinggian Air Berbasis Web dan SMS Gateway. Sisfotenika, 5(2), 119-129. http://dx.doi.org/10.30700/jst.v5i2.85

Watty, M., Elektro, J. T., Teknik, F., \& Kartika, U. W. (2019). Pengendali Ketinggian Air Menggunakan Sensor Ultrasonic Dengan Metode Fuzzy Logic. Jurnal Sistem Cerdas Dan Rekayasa (JSCR), 1(1), 76-86. 
Wibowo, I. (2017). Sistem Pemantau Ketinggian Air Nirkabel Wireless Water Level Monitoring System. TELEKONTRAN, 5(1), 49-53.

Yusman. (2013). Telemetri Pemantauan Ketinggian Air Sungai Melalui Komputer Teroptimasi Database Berbasis SMS. Jurnal Teknologi, 13(1), 25-28. 